\title{
Up-Regulation of Glioma-Associated Oncogene Homolog 1 Expression by Serum Starvation Promotes Cell Survival in ER-Positive Breast Cancer Cells
}

\author{
Juan Xu $\mathrm{u}^{\mathrm{b}, \mathrm{c}}$ Gaoxiang Huang ${ }^{\mathrm{a}}$ Zongjing Zhang ${ }^{\mathrm{b}}$ Jieying Zhao ${ }^{\mathrm{a}}$ \\ Mingzhuo Zhang ${ }^{a}$ Yan Wang ${ }^{a}$ Zhimin Liub Jian Lu \\ aDepartment of Pathophysiology, School of Basic Medicine, Second Military Medical University, \\ Shanghai, 'Department of Endocrinology, Changzheng Hospital, Second Military Medical University, \\ Shanghai, 'The present address: the Department of Geriatrics, the 117th Hospital of PLA, Hangzhou, \\ Zhejiang, People's Republic of China
}

\section{Key Words}

Gli1 $•$ Breast cancer $\cdot$ Cell survival $\cdot$ CIAP2 $・ N F-\kappa B$

\begin{abstract}
Background/Aims: Cancer cells are resistant to ischemia and starvation. Glioma-associated oncogene homolog 1 (Gli1) is a positive transcriptional activator of Hedgehog (Hh) pathway and plays an essential role in the development of cancers, including breast cancer. However, how Gli1 promotes cell survival remains elusive. The main purpose of this study is to investigate the pro-survival effect of Gli1 under serum starvation and its molecular mechanism in ERpositive breast cancer cells. Methods: Gene expression was determined by quantitative realtime PCR (QRT-PCR) and Western blot. The survival of Gli1 stably transfected ER-positive breast cancer cell lines (Gli1-MCF-7 and Gli1-T47D cells) and their untransfected control cells was estimated by WST-8 assay. Microarray analysis was performed to screen downstream $\mathrm{Hh} / \mathrm{Gli1}$ target genes in Gli1-overexpressed MCF-7 cells. Transcriptional activities of NFkappaB were measured by luciferase assays. ChIP analysis was performed to explore whether CIAP2 was a direct target gene of Gli1. Results: Serum starvation significantly up-regulated the expression of Gli1 gene through activating PI3K/AKT pathway. Over-expression of Gli1 markedly promoted cell survival under serum starvation. Microarray analysis revealed that 338 genes were differentially expressed in Gli1-MCF-7 cells compared with those in the control cells. Among these genes, cellular inhibitor of apoptosis 2 (cIAP2), coding an anti-apoptosis and pro-survival protein, was significantly up-regulated not only by Hh/Gli1 pathway, but also by serum starvation. However, ChIP assay revealed no binding of Gli1 to CIAP2 promoter at the region of -1792 to $-1568 \mathrm{bp}$. Moreover, over-expression of Gli1 resulted in enhanced transactivation of transcriptional factor NF-kB. Suppression of NF- $\mathrm{kB}$ signaling with NF-kB inhibitor

J. Xu and G. Huang contributed equally to this work.

Jian Lu

and Zhimin Liu

Department of Pathophysiology, Second Military Medical University, 800 Xiang-Yin Road, Shanghai 200433, (People's Republic of China); and Department of Endocrinology, Changzheng Hospital, Second Military Medical University, Shanghai, 200001 (People's Republic of China); E-Mail lujian326@163.com, E-Mail liuzm_cz@hotmail.com
\end{abstract}

KARGER 125 
Bay11-7082, significantly reduced the expression of CIAP2 and the cell survival under serum starvation. Conclusion: Serum starvation significantly up-regulated the expression of Gli1, which in turn increased its key target cIAP2 expression and enhanced NF-KB/cIAP2 pathway, resulting in promoting cell survival under serum starvation. These findings may provide new insights into the pro-survival mechanisms of Gli1 in breast cancer.

Copyright (C) 2015 S. Karger AG, Basel

\section{Introduction}

Glioma-associated oncogene homolog (Gli) family includes Gli1, Gli2 and Gli3, which are zinc finger transcription factors and act as nuclear mediators of the Hedgehog ( $\mathrm{Hh}$ ) signaling pathway. Gli1 functions as a strong positive transcriptional activator of the downstream of Hh pathway, whereas Gli2 and Gli3 function as either transcriptional activators or repressors. They coordinately regulate the expression of genes [1]. The activation of the canonical $\mathrm{Hh}$ pathway is initiated by the secreted Sonic Hedgehog (Shh) ligand that binds to its receptor PTCH and then relieves the repression of the Smoothened (Smo). Activated Smo releases Glis from cytoplasmic sequestration mediated by a protein complex and allows the translocation of Glis to the nucleus [2, 3], where Gli1 binds to a consensus Gli1-binding element within target genes and results in their activation [4]. Notably, Gli1 itself is a transcriptional target of Hh signaling [5]. Gli1 expression and activity are modulated not only by the Hh pathway, but also by other signaling pathways, such as transforming growth factor beta(TGF $\beta$ ), Ras/ ERK, phosphatidylinositol-3-kinase(PI3K)/AKT, etc [6-8].

The Hh/Gli1 pathway plays an essential role in vertebrate organogenesis as well as the development of some cancers by regulating proliferation, differentiation, epithelialmesenchymal transition and survival [9-12]. The aberrant activation of Hh pathway has been described in a growing number of cancers, including breast cancer cells [13-17]. Studies have shown that the Hh ligand or Gli1 was abnormally expressed in breast cancer tissues and cells, which was associated with tamoxifen-resistance of breast cancer cells [7], increased metastasis risk and poor survival of breast cancer patients [7, 13, 14, 18-20]. Moreover, advanced mammary tumors developed in transgenic mice, in which Gli1 was conditionally expressed under the control of a doxycyclin-inducible MMTV promoter in the mammary gland epithelium [21]. Our previous study found that the stable expression of Gli1 in ER-positive breast cancer cell lines MCF-7 and T47D induced estrogen-independent proliferation and promoted G1/S phase transition [22]. These findings reveal that the activation of Hh/Gli1 pathway facilitates growth and progression of breast cancer. However, the precise mechanism, by which Gli1 contributes to breast cancer development, remains unclear.

Tumor microenvironment is a characteristic of ischemia and starvation of nutrient. Cancer cells are capable of enhancing their resistance to unfavorable microenvironment to promote cell survival, which is very important for development of cancer. In present study, we investigated the expression and pro-survival effect of Gli1 under serum starvation and the possible mechanisms of pro-survival of the gene by identifying its target genes and signaling pathway in ER-positive breast cancer cells. This study facilitates understanding the pro-survival mechanisms of Gli1 and promotes the development of novel therapeutic strategies.

\section{Materials and Methods}

Reagents and plasmids

Wortmanin and Bay11-7082 were purchased from Sigma-Aldrich (St. Louis, MO, USA) and dissolved in dimethyl sulfoxide (DMSO). Recombinant human SHH N-terminus (rhSHH-N, R\&D system, Minneapolis, MN, 


\section{Cellular Physiology Cell Physiol Biochem 2015;36:1862-1876

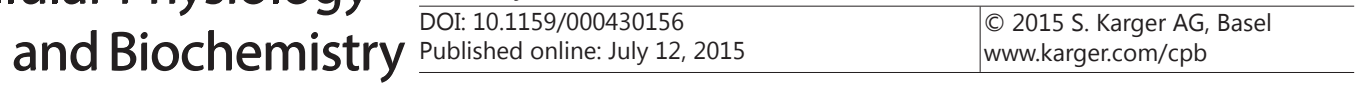

Xu et al.: Gli1 Promotes Survival of Breast Cancer Cells

USA) was dissolved in PBS containing $0.1 \%$ bovine serum albumin (BSA) according to the manufacturer's recommendation. Human Gli1 expression vector pcDNA3.1-Gli1 and the vehicle vector pcDNA3.1 were provided by Dr. Hiroshi Sasaki (RIKEN Kobe, Japan). The pGL3-NF-kB-luc containing two-copies of wildtype NF-кB-luc-responsive elements was kindly provided by Dr. H.M. Xu [23]. The pRL-SV40-luc vector was obtained from Promega (Madison, WI, USA).

\section{Cell culture and drug treatment}

The human breast cancer cell lines MCF-7 and T47D are estrogen receptor (ER) positive cells that express ERs and grow in response to the estrogen. These cells were incubated at $37^{\circ} \mathrm{C}$ and in $5 \% \mathrm{CO}_{2}$ humidified atmosphere with the RPMI-1640 medium (Invitrogen, Carlsbad, CA, USA) containing 10\% fetal bovine serum (FBS) (PAA, Pasching, Austria), 100U/ml penicillin and $100 \mu \mathrm{g} / \mathrm{ml}$ streptomycin (Huashun Technology, Inc., Shanghai, China). For Wortmanin treatment, cells were $60 \%-70 \%$ confluent and then treated with 100nM Wortmanin or an equimolar amount of vehicle DMSO in phenol-red free RPMI-1640 containing $2.5 \%$ or $0.5 \%$ charcoal-dextran stripped FBS (CD-FBS) to avoid possible interference with serum endogenous steroids for $24 \mathrm{~h}$.

\section{Establishment of stable cell lines}

The cells were seeded at $1 \times 10^{6}$ per $60 \mathrm{~mm}$ culture dishes for $24 \mathrm{~h}$ and then were transiently transfected with $8.0 \mu \mathrm{g}$ pcDNA3.1-Gli1 or pcDNA3.1 plasmids using Lipofectamine ${ }^{\mathrm{TM}} 2000$ Transfection Reagent (Invitrogen) per manufacturer's instructions. After $48 \mathrm{~h}$, the cells were plated at a low density in medium

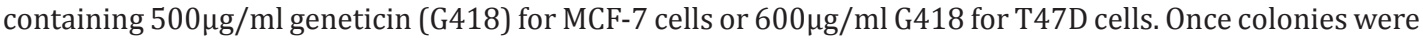
formed, individual colonies were isolated and expanded. The cells were continuously maintained in medium containing $250 \mu \mathrm{g} / \mathrm{ml} \mathrm{G} 418$ for MCF-7 or $300 \mu \mathrm{g} / \mathrm{ml} \mathrm{G418} \mathrm{for} \mathrm{T47D.}$

\section{RNA extraction and quantitative real-time PCR}

Total RNA was extracted using Trizol reagent (Invitrogen, Carlsbad, USA) and $2 \mu \mathrm{g}$ total RNA was reversely transcribed using Reverse Transcription Reagents (MBI Fermantas, Vilnius, Lithuania) following manufacturer's protocol. Quantitative real-time PCR (QRT-PCR) was performed in triplicate using SYBR Green PCR Master Mix (Toyobo, Japan) on a Mastercycler ep realplex (Eppendorf, German). The mRNA levels were normalized to GAPDH (internal control) and relatively quantified by the DDCt method. Primer sequences were listed in Table1.

\section{Western blotting analysis}

Total cell lysates were prepared with $1 \times$ SDS lysis buffer with $100 \mathrm{mM}$ Dithiothreitol and $2 \mu \mathrm{g} / \mathrm{ml}$ protease inhibitors containing $0.1 \mathrm{mM}$ leupeptin, aprotinin, and pepstatin. After electrophoresis, proteins were transferred to nitrocellulose membrane, blocked with 5\% nonfat milk, and probed overnight with primary antibodies against Gli1 (1:200; Abcam, MA, USA), $\beta$-actin (1:10000, Sigma-Aldrich Chemicals, St. Louis, MO, USA), cIAP2 (1:200, Biolegend, CA, USA), p-Akt1/2/3 (Ser 473) (sc-7985, 1:1000, Santa Cruz, Texas, USA), Akt1/2/3 (sc-8312, 1:1000, Santa Cruz, Texas, USA). The membranes were washed three times and incubated with HRP-conjugated secondary antibodies (1:5000, Rockland Immunochemicals, PA, USA) for $2 \mathrm{~h}$. Finally blots were detected by ECL chemiluminescence (Pierce, Rockford, IL, USA). Protein bands were quantified with ImageJ software $(\mathrm{NIH})$ using $\beta$-actin as an internal control.
Table 1. Primers for amplification of genes in this study. F: forward; R: reward

\begin{tabular}{ll}
\hline Gene & Primer sequence \\
\hline GAPDH & F: 5'-CATGAGAAGTATGACAACAGCCT-3' \\
& R: 5'-AGTCCTTCCACGATACCAAAGT-3' \\
GLI1 & F: 5'-GGAAGTCATACTCACGCCTCGA-3' \\
& R: 5'-CATTGCTGAAGGCTTTACTGCA-3' \\
cIAP2 & F: 5'-AGCTGAAGCTGTGTTATATGAGC-3' \\
& R: 5'-ACTGTACCCTTGATTGTACTCCT-3' \\
UBD & F: 5'-CCGTTCCGAGGAATGGGATTT-3' \\
& R: 5'-GCCATAAGATGAGAGGCTTCTCC-3' \\
SLFN5 & F: 5'-GAGTGTGTTGTAGATGCAGGAA-3' \\
& R: 5'-ACTGCTCGCAGGATGATTTCA-3' \\
CSAG1 & F: 5'-GATCCAGCCAGGGCAGAG-3' \\
& R: 5'-TCTTGGGAACCTCTTTGGTGT-3' \\
SLPI & F: 5'-GAGATGTTGTCCTGACACTTGTG-3' \\
& R: 5'-GCTTCCTCCTTGTTGGGTTTG-3' \\
NDRG1 & F: 5'-CTCCTGCAAGAGTTTGATGTCC-3' \\
& R: 5'-AGAGCCATGTAAAGTCTCGATGT-3' \\
ROCK1 & F: 5'-AACATGCTGCTGGATAAATCTGG-3' \\
& R: 5'-TGTATCACATCGTACCATGCCT-3' \\
\hline
\end{tabular}


Table 2. List of differentially expressed genes by cDNA microarray analysis

\begin{tabular}{|c|c|c|c|}
\hline Function & Accession & Gene & Ratio \\
\hline \multirow{4}{*}{ Metabolism } & NM_001353 & AKR1C1 & 6.1395 \\
\hline & NM_001354 & AKR1C2 & 7.04 \\
\hline & NM_003739 & AKR1C3 & 4.1276 \\
\hline & NM_001818 & AKR1C4 & 7.8424 \\
\hline \multirow{4}{*}{ Apoptosis } & NM_182962 & cIAP2 & 6.5846 \\
\hline & NM_004874 & BAG4 & 0.4672 \\
\hline & NM_006290 & TNFAIP3 & 2.5447 \\
\hline & NM_012385 & NUPR1 & 3.0479 \\
\hline \multirow{11}{*}{ Cytoskeleton } & NM_019114 & EPB41L4B & 6.6875 \\
\hline & NM_007124 & UTRN & 4.8194 \\
\hline & NM_003088 & FSCN1 & 2.3869 \\
\hline & NM_002298 & LCP1 & 2.1482 \\
\hline & NM_006207 & CFL2 & 2.8904 \\
\hline & NM_016357 & LIMA1 & 0.4886 \\
\hline & NM_005219 & DIAPH1 & 0.4351 \\
\hline & XM_086186 & SYDE2 & 0.3112 \\
\hline & NM_014547 & TMOD3 & 0.3955 \\
\hline & NM_006096 & NDRG1 & 0.3062 \\
\hline & NM_006197 & PCM1 & 0.4887 \\
\hline \multirow{4}{*}{$\begin{array}{l}\text { Regulation of inflammatory } \\
\text { response }\end{array}$} & NM_002982 & CCL2 & 22.5694 \\
\hline & NM_002985 & CCL5 & 3.1066 \\
\hline & NM_005408 & CCL13 & 2.6249 \\
\hline & NM_030754 & SAA2 & 1691.37 \\
\hline \multirow{8}{*}{ Innate immunity } & NM_005514 & HLA-B & 15.1126 \\
\hline & NM_002117 & HLA-C & 6.7695 \\
\hline & NM_005516 & HLA-E & 3.2261 \\
\hline & NM_018950 & HLA-F & 5.8991 \\
\hline & NM_002127 & HLA-H/HLA-G & 14.7074 \\
\hline & NM_002125 & HLA-DRB5 & 3.3043 \\
\hline & NM_033554 & NP_061984.2 & 69.5012 \\
\hline & NM_022555 & HLA-DRB3 & 6.2563 \\
\hline \multirow{10}{*}{ Proliferation } & NM_001287188 & ODC1 & 2.5858 \\
\hline & NM_001204502 & FLT3LG & 3.2152 \\
\hline & NM_003088 & FSCN1 & 2.3869 \\
\hline & NM_005862 & STAG1 & 0.2242 \\
\hline & NM_003157 & NEK4 & 0.3464 \\
\hline & NM_015384 & NIPBL & 0.355 \\
\hline & NM_006472 & TXNIP & 0.3877 \\
\hline & XM_088331 & $\mathrm{ESCO} 2$ & 0.3945 \\
\hline & NM_020382 & SETD8 & 0.4844 \\
\hline & NM_057749 & CCNE2 & 0.288 \\
\hline
\end{tabular}

WST-8 assay for cell viability

Following the standard procedures provided by manufacturer, cell viability was evaluated by WST8 assay modified from a method using Cell Counting Kit-8 (CCK-8, Dojindo Molecular Technologies, Inc., Japan). $1 \times 10^{3}$ cells were plated in 96 -well plates in triplicate, and then allowed to adhere overnight. Next day ( 0 day), the medium was removed and the cells were incubated in phenol-red free RPMI-1640 containing $0.5 \%$ CD-FBS for indicated times. The cells were refreshed every other day and cell viability was measured on set days. Then, the optical density (O.D.) was measured at a wavelength of $450 \mathrm{~nm}$ using a Labsystem multiskan microplate reader (Merck Eurolab, Dietikon, Switzerland).

\section{Microarray analysis}

Following the manufacturer's instructions, the stable subclone Gli1-MCF-7 and mock-transfected cells were picked. Oligonucleotide array analysis was performed by the CapitalBio Corp. (Beijing, P.R. China) using a 35K Human Genome Array containing 35,035 70-mer probes representing 25,100 human gene transcripts. Data processing and normalization were performed according to standard procedures using a LOWESS program. The raw microarray data were released into the GEO-database (accession number GSE53729) and 


\section{Cellular Physiology Cell Physiol Biochem 2015;36:1862-1876 \begin{tabular}{l|l} 
and Biochemistry Published onIIne: July 12, 2015 & $\begin{array}{l}\text { C) 2015 S. Karger AG, Basel } \\
\text { www.karger.com/cpb }\end{array}$ \\
\hline
\end{tabular} \\ Xu et al.: Gli1 Promotes Survival of Breast Cancer Cells}

linked to http://www.ncbi.nlm.nih.gov/geo/query/acc.cgi?token=opwrmowetzijrmb\&acc=GSE53729. The genes shown in Table2 were at least two-fold up-regulated or down-regulated in stable Gli1-MCF-7 cells.

ChIP assay

Chromatin immunoprecipitation assay were performed according to the instructions of the EZ ChIP ${ }^{\mathrm{TM}}$ Kit (Millipore) with minor modifications. Briefly, pcDNA3.1-MCF7 cells and pGli1-MCF7 cells were crosslinked and sonicated. Equal amounts of lysates were used for immunoprecipitation of chromatin with specific antibodies: Gli1 (R\&D system), acetyl-histone H3 and normal mouse IgG (Millipore). The purified chromatin DNA was subjected to quantitative real-time PCR with primers for promoter of human cIAP2 gene, with acetyl-histone $\mathrm{H} 3$ as a positive control and immunoglobulin $\mathrm{G}$ as a negative control. The primers were 5' -CCAAGTAGCTGGGACTACAGGC-3' (sense) and 5'-CTGGGATCATAAGGATCTAAGTGTTA-3' (antisense). The data were analyzed using the formula of $2^{-\Delta \Delta C t}$, where $\Delta \Delta \mathrm{CT}=(\mathrm{Ct}[\mathrm{IP}]-\mathrm{Ct}[\text { input }])_{\mathrm{SA}}-(\mathrm{Ct}[\mathrm{IP}]-\mathrm{Ct}[\mathrm{input}])_{\mathrm{NS}}{ }^{*}$ $\mathrm{SA}=$ Specific antibody, NS= Non-specific antibody. Three independent ChIPs were performed.

\section{Luciferase assay}

The cells were plated in triplicate into a 24 -well plate at a density of $5 \times 10^{4}$ cells/well for $24 \mathrm{~h}$, and then were transiently co-transfected with a DNA mixture containing pGL3-NF- $\kappa B-l u c$ (200ng/well), pcDNA3.1Gli1 (500ng/well) or pcDNA3.1 vector (500ng/well) using Lipofectamine ${ }^{\mathrm{TM}} 2000$ Transfection Reagent (Invitrogen) for 24h. 1.0ng pRL-SV40-luc per well was co-transfected to normalize the transfection efficiency. The luciferase activity was determined by the dual luciferase assay system. Results were normalized against the internal renilla control and presented as fold induction over control.

\section{Statistical analysis}

Data were expressed as Mean \pm SD of at least three determinations. Statistical significance between experimental groups was analyzed by ANOVA and the significant level was set at $P<0.05$.

\section{Results}

Serum starvation induces the expression of Gli1 through activation of PI3K/AKT pathway in breast cancer cell lines

Tumor microenvironment is a characteristic of ischemia and starvation of nutrients, and the enhanced resistance of cancer cells to ischemia- and starvation-induced cell death plays a very pivotal role in cancer progression. First we examined the expression of Gli1 in MCF-7 and T47D cells cultured in medium containing decreasing serum concentration (5\%, $2.5 \%$ and $0.5 \%$ ) using QRT-PCR and Western blotting. We found that the expression of Gli1 was increased with decreasing the serum concentration. The mRNA levels of Gli1 in MCF-7 and T47D cells cultured in $0.5 \%$ CD-FBS medium increased by 2.67 fold $(P<0.05)$ and 2.23 fold $(P<0.05)$ compared with that cultured in 10\% CD-FBS medium, respectively (Fig. 1A). Similarly, increased Gli1 proteins were also observed by Western blotting analysis in both cell lines (Fig. 1B). These results indicate that serum starvation up-regulates the expression of Gli1 in breast cancer cells.

AKT is a serine/threonine kinase downstream of PI3K. The PI3K/AKT pathway plays a critical role in cell survival, proliferation, metabolism and resistance to apoptosis [24, 25]. It has been reported that the expression and activity of Gli1 are modulated by PI3K/ AKT pathway [7, 26, 27]. We therefore examined whether up-regulation of Gli1 by serum starvation was through the activation of PI3K/AKT pathway. Results showed that the level of phosphorylated AKT at S473 was significantly increased in MCF-7 and T47D cells cultured in $0.5 \%$ CD-FBS medium for $24 \mathrm{~h}$ compared with that in cells cultured in medium with $10 \% \mathrm{CD}$ FBS (Fig. 1C). Treatment with 100nM of Wortmanin, a specific inhibitor of PI3K, significantly decreased the levels of Gli1 protein and mRNA in MCF-7 cells and T47D cells under a serumstarved condition (Fig. 1C and D). These results indicate that serum starvation up-regulates the expression of Gli1 at least in part through the activation of PI3K/AKT pathway.

\section{KARGER}


Fig. 1. Effect of serum starvation on Gli1 expression in breast cancer cells. Breast cancer cells (MCF-7 and T47D) were cultured for $24 \mathrm{~h}$ in complete medium and then in medium containing indicated concentrations of serum for another 24h. Gli1 mRNA (A), Gli1 protein (B) were detected by QRT-PCR and Western blotting, respectively. The cells grew for $24 \mathrm{~h}$ in complete medium and then were treated with $100 \mathrm{nM}$ Wortmanin, or an equimolar amount of DMSO in phenol-red free RPMI1640 containing indicated concentrations of CD-FBS for another $24 \mathrm{~h}$. Indicated proteins (C) and Gli1 mRNA (D) were evaluated in MCF-7 and T47D cells by Western blot and QRT-PCR, respectively. GAPDH was used as a normalization control for QRT-PCR

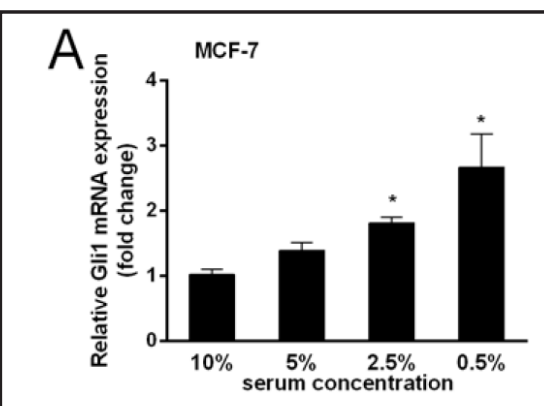

B

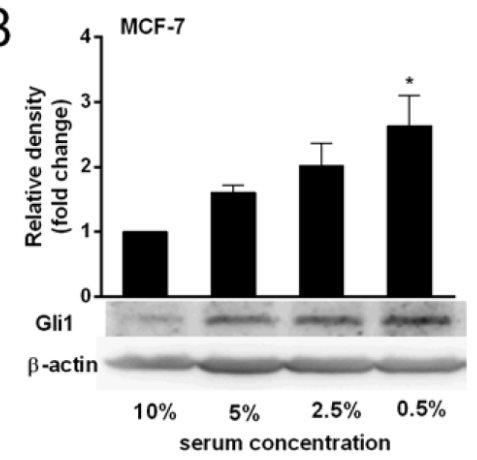

C
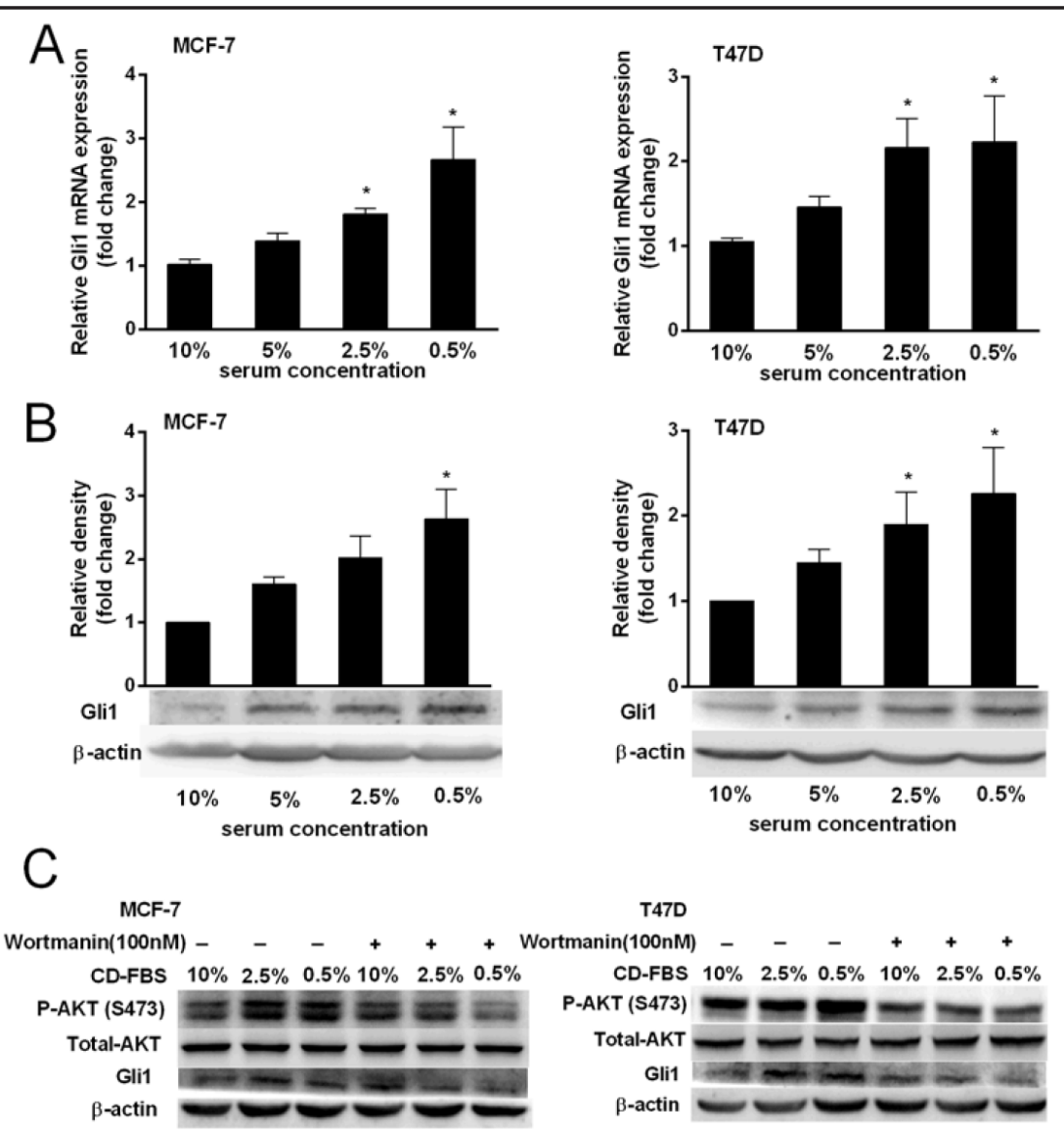

D
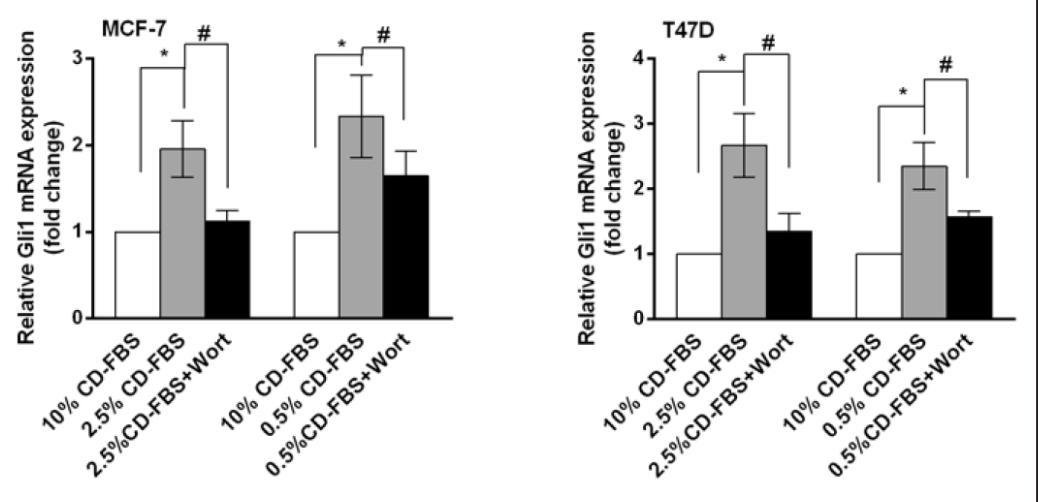

and $\beta$-actin as a loading control for Western blotting. The results were expressed as fold over control cells in complete medium. Data were representative of three independent experiments. Each bar represents mean \pm S.D. ${ }^{*} P<0.05$ versus the $10 \%$ group. $\# P<0.05$ versus the cells treated with the vehicle.

Over-expressed Gli1 promotes survival of breast cancer cells cultured in serum-starved medium

Serum supports cell growth by providing a broad spectrum of nutrients, hormones (such as estrogen), growth factors and attachment factors. Other groups had also reported that serum starvation could reduce cell viability and induce cell apoptosis [28, 29]. Our previous studies also demonstrated that serum starvation (0.5\% CD-FBS) obviously decreased cell proliferation and increased cell death (data not shown). Therefore, we then examined whether up-regulation of Gli1 expression could promote survival of breast cancer cell in a serum-starved condition using established stable Gli1-transfectants (Gli1-MCF-7 and Gli1- 
Fig. 2. Effect of over-expressing Gli1 on breast cancer cell survival in serum-starved medium The cells were transfected with pcDNA3.1-Gli1 or control plasmid, and single-cell-derived clones were obtained as described in "Materials and methods". The mRNA (A) and protein (B) levels of Gli1 in control cells and Gli1-transfectants were analyzed by QRT-PCR and Western blotting, respectively. GAPDH was used as a normalization control for QRT-PCR and $\beta$-actin as a loading control for Western blotting. (C and D) Stably Gli1-overexpressing breast cancer

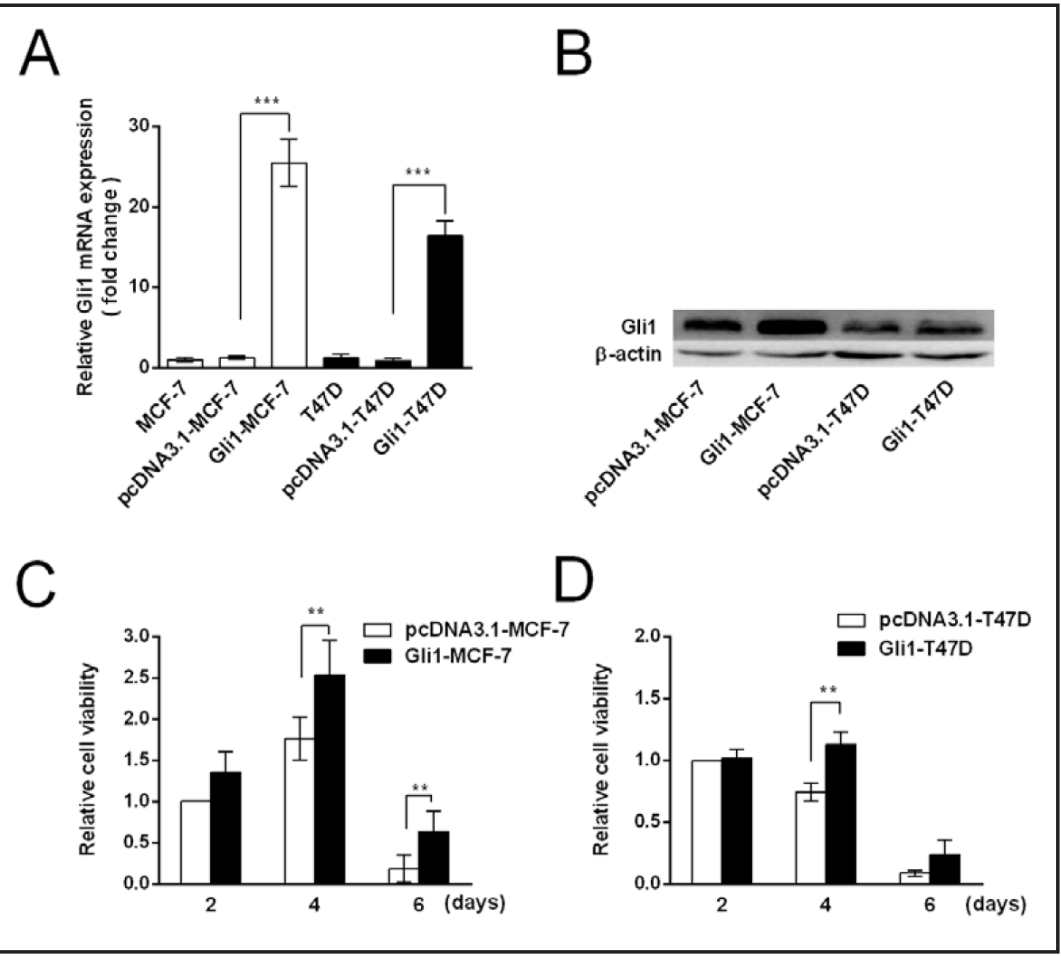
cells (MCF-7 and T47D) and corresponding control ones (1,000 cells/ well) were plated in 96-well plates and allowed to adhere overnight. Next day ( 0 day), the medium was removed and the cells were incubated in medium containing $0.5 \%$ CD-FBS as indicated for different days. Cell viability was evaluated by WST-8 cell viability assay. Data were representative of three separate experiments and expressed as mean $\pm \mathrm{SD}$. ${ }^{* *} P<0.01,{ }^{* * *} P<0.001$ versus corresponding empty vector control.

T47D cells) and their control cells (pcDNA3.1-MCF-7 and pcDNA3.1-T47D). The increased expression of Gli1 mRNA and protein in Gli1-transfectants were confirmed by QRT-PCR (Fig. 2A) and Western blotting (Fig. 2B). The cell survival in a serum-starved condition was assayed by WST-8 cell viability analysis at indicated time points. As shown in Fig 2C, the viability of Gli1-MCF-7 cells was higher than control cells in medium with $0.5 \%$ CDFBS at day 4 and 6 (1.4 and 2.7 fold of control, $P<0.01$, respectively) (Fig. 2C). Similarly, the significantly increased viability was also observed in Gli1-T47D cells in medium with $0.5 \%$ CD-FBS at day 4 (1.53 fold of control, $P<0.01$ ) (Fig. 2D).

\section{Identifying Gli1-regulated genes in MCF-7 cells by microarray analysis}

In order to screen for downstream Hh/Gli1 target genes that are likely to be involved in pro-survival effect of Gli1 in breast cancer cells, microarray analysis was performed on Gli1MCF-7 cells over-expressing Gli1 and mock-transfected cells. Results of three independent microarray experiments showed that 179 genes were significantly up-regulated by at least two-fold ( $\geq 2$-fold), whereas 159 targets were down-regulated by at least $50 \%$ as compared with the control cells (Fig. 3A). All of the 338 Gli1-regulated genes could be further divided into six functional groups: metabolism, apoptosis, cytoskeleton, proliferation, inflammation and innate immunity (Table2). Among Gli1-regulated genes, five up-regulated targets, including cIAP2 (cellular inhibitor of apoptosis 2), SLFN5 (a member of the Schlafen family), SLPI (secretory leucocyte protease inhibitor), UBD (Ubiquitin D/ Ubiquitin-like protein FAT 10), CSAG1 (chondrosarcoma associated gene 1) and two down-regulated targets, NDRG1 (a member of the N-myc down-regulated family) and ROCK1 (rho-associated, coiled-coilcontaining protein kinase 1) were further confirmed by QRT-PCR in Gli1-MCF-7 cells (Fig. 3B). Except CSAG1 and ROCK1, similar up-regulation of cIAP2, SLFN5, UBD, SLPI genes and down-regulation of NDRG1 gene were also seen in Gli1-T47D cells (Fig. 3C). 


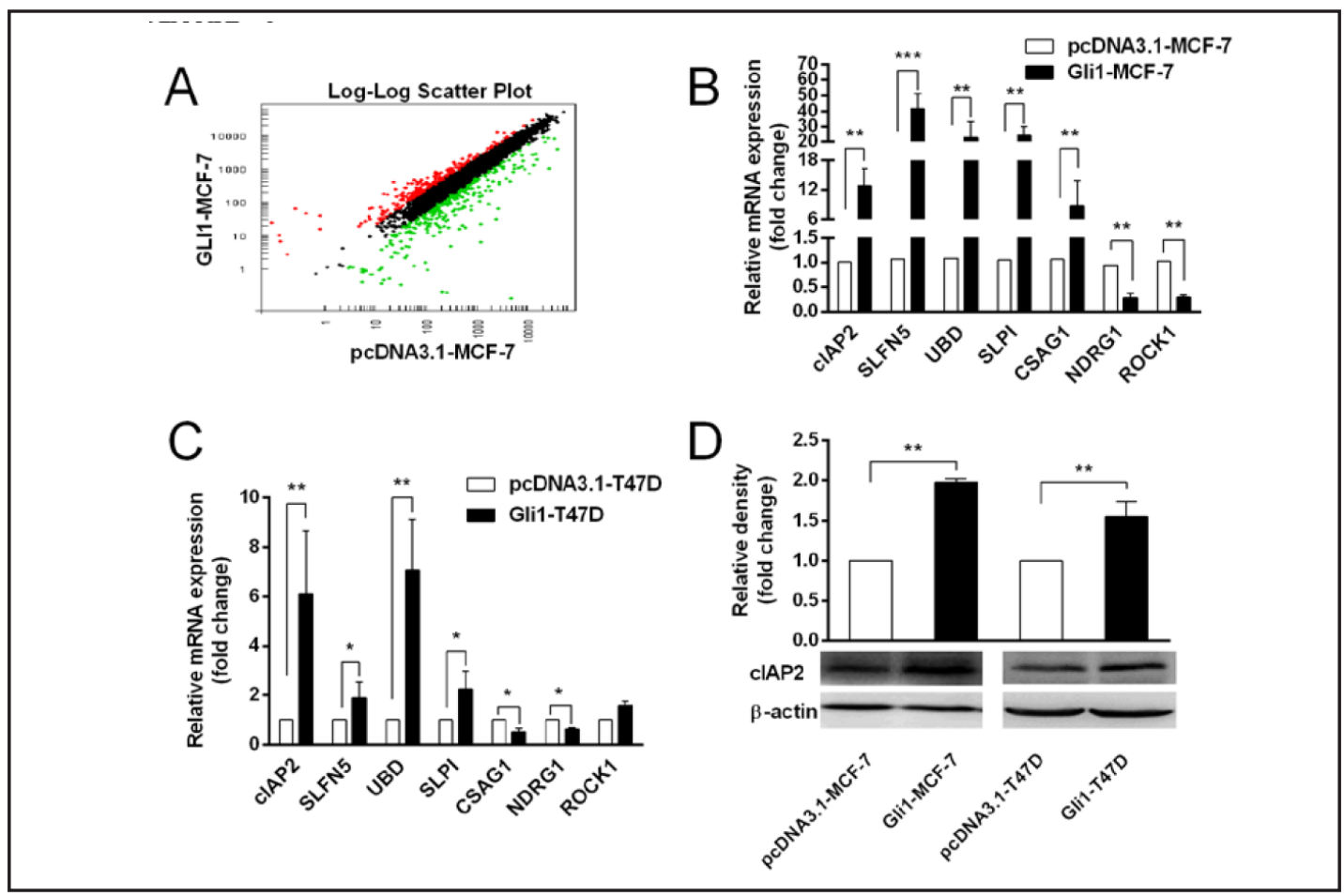

Fig. 3. Validation and identification of Gli1-regulated genes in breast cancer cells. (A) Microarray analysis was performed as described in "Materials and methods". Log-Log Scatter plot showed genes differentially expressed between Gli1-MCF-7 and pcDNA3.1-MCF-7 cells (high expression in red and low expression in green). Five up-regulated genes and two down-regulated genes were confirmed by QRT-PCR in the stably transfected MCF-7 (B) or T47D (C) cells. cIAP2 protein expressions were determined by Western blotting (D) in stably transfected MCF-7 and T47D cells. GAPDH was used as a normalization control for QRT-PCR and $\beta$-actin as a loading control for Western blotting. Data were representative of three independent experiments and expressed as mean \pm S.D. ${ }^{*} P<0.05$, ${ }^{* *} P<0.01,{ }^{* * *} P<0.001$ versus the empty vector control.

Among genes identified by microarray, the expression of three anti-apoptosis genes, including cIAP2, TNFAIP3 (TNF- $\alpha$-induced protein 3) [30] and NUPR1 (nuclear protein 1) [31] were up-regulated, and the most highly up-regulated gene was CIAP2 that has wellestablished functions as an anti-apoptotic and pro-survival protein [32-34]. The mRNA levels of cIAP2 tested by QRT-PCR increased by about 12 fold in Gli1-MCF-7 $(P<0.01)$ and 7 fold in Gli1-T47D cells $(P<0.01)$ compared with their control cells (Fig. 3B and C). The increased protein levels of cIAP2 in Gli1-transfectants were further confirmed by Western blotting analysis in breast cancer cell lines (Fig. 3D).

\section{No direct binding of Gli1 to cIAP2 promoter region was found}

In order to know whether cIAP2 is a direct target gene of Gli1, we searched putative Gli1 binding site in the promoter region of CIAP2 gene through online transcription element search software analysis. Within $-1681 \mathrm{bp}$ to $-1741 \mathrm{bp}$ promoter region of CIAP2 gene, we found a putative Gli1 binding site (5'-GATCCACCCA-3') that resembles a known consensus sequence of human Gli-binding site (5-GACCACCCA-3) [4, 35] (Fig. 4A). We further performed ChIP assay to figure out whether there is a direct binding of Gli1 to the promoter of CIAP2 gene at the region of -1568 to $-1792 \mathrm{bp}$. Isotype control IgG and anti-acetyl-histone H3 were used as negative and positive controls. However, no direct binding of Gli1 to this region was found (Fig. 4B), suggesting that Gli1 might regulate the expression of cIAP2 in an indirect manner. 
Fig. 4. No direct binding of Gli1 to the region of -1568 to -1792 bp in the CIAP2 promoter. (A) Schematic representation of human CIAP2 gene showing the relative location of DNA sequences that closely match Gli consensus binding site within about $3 \mathrm{~kb}$ of the transcription initiation site. (B) ChIP assay was performed in pcDNA3.1-MCF7 and pGli1-MCF7 cells using indicated antibodies. Isotype control IgG and anti-acetyl-histone H3 were used as negative and positive controls, respectively. Data showed no recruitment of Gli1 to the promoter of CIAP2 gene with primers listed in "Materials and methods". All values were normalized by control IgG precipitations. Each bar represented the average result from three independent ChIP experiments. ${ }^{*} P<0.05$ versus anti-control IgG.

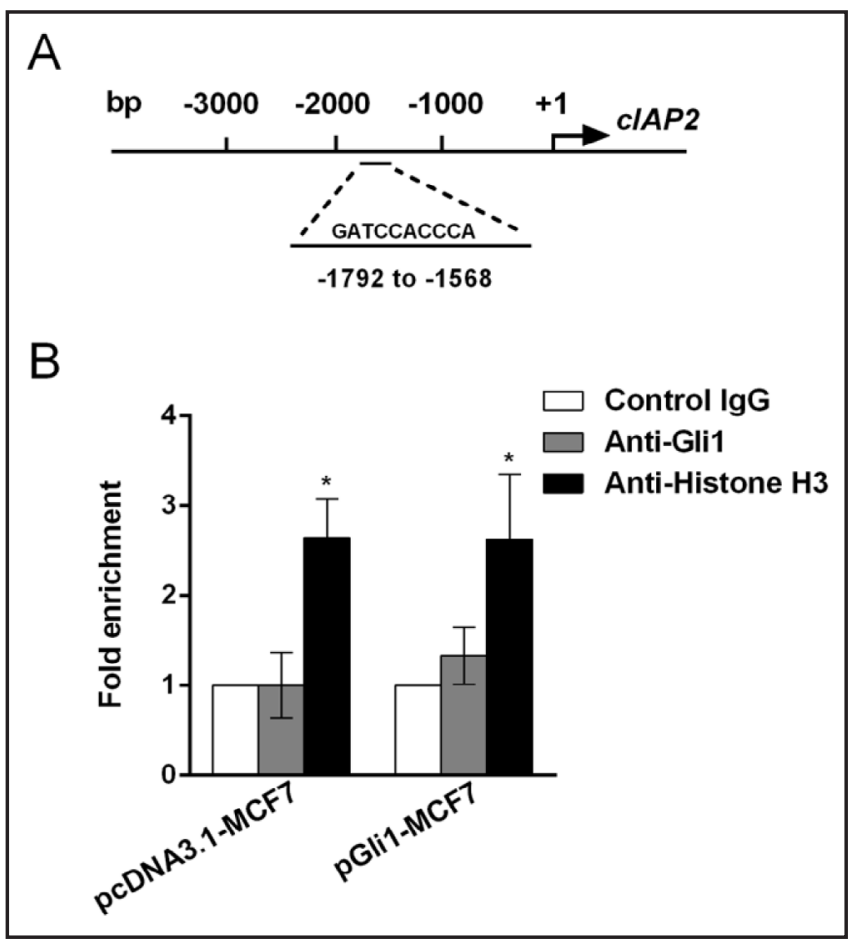

CIAP2 expression is up-regulated by Hedgehog/Gli1 signaling pathway and serum starvation in breast cancer cells

Given that Gli1 is up-regulated by either $\mathrm{Hh}$ ligand-dependent or -independent mechanisms, we examined whether the expression of cIAP2 is up-regulated by ligand of Hh/Gli1 pathway. MCF-7 and T47D cells were treated with $0.4 \mu \mathrm{g} / \mathrm{ml} \mathrm{rhSHH}-\mathrm{N}$, a ligand of hedgehog pathway, for different time ( $4 \mathrm{~h}, 8 \mathrm{~h}, 12 \mathrm{~h}$, and $24 \mathrm{~h}$ ), and then Gli1 and cIAP2 mRNA were determined. The results showed that significant increases in Gli1 and cIAP2 mRNA levels by rhSHH-N were only seen in MCF-7 cells for $4 \mathrm{~h}$ ( 4.5 and 2.3 fold of controls, $P<0.01$, respectively) or T47D cells for $12 \mathrm{~h}$ ( 2.3 and 1.9 fold of controls, $P<0.05$, respectively) (Fig. $5 A)$. There was no significant change at other time points. This result indicated that $\mathrm{Hh}$ ligand could shortly up-regulate the expression of Gli1 and cIAP2.

It was showed that serum starvation up-regulated the expression of Gli1 and overexpressed Gli1 enhanced the survival of breast cancer cells. Therefore, we hypothesized that Gli1-induced the expression of cIAP2 may account in part for the pro-survival effect of Gli1 under serum starvation. Being consistent with this hypothesis, cIAP2 mRNA and protein levels in both MCF-7 cells and T47D cells cultured in medium with $0.5 \%$ serum concentration were significantly increased and the regulation patterns and extent of cIAP2 were similar to Gli1 (Fig. 5B and C), strongly suggesting that cIAP2 might be involved in the pro-survival effect of Gli1.

$N F-\kappa B / c I A P 2$ signaling partially contributes to the pro-survival role of Gli1 in ER-positive breast cancer cells

Activation of the transcription factor NF- $\mathrm{\kappa B}$ is a key pro-survival mechanism in cancer cells [36] and studies have shown that cIAP2 is a target gene of NF- $\mathrm{BB}[37,38]$. Therefore, we examined whether NF- $\kappa \mathrm{B}$ activation is involved in the pro-survival effect of Gli1 as well as up-regulation of cIAP2 expression. The cells were transiently transfected with a DNA mixture containing pGL3-NF-KB-luc, pRL-SV40-luc, pcDNA3.1-Gli1 or pcDNA3.1 vector for $24 \mathrm{~h}$, and then the luciferase activities were determined using the dual luciferase assay system. As shown in Fig. 6A, over-expression of Gli1 significantly increased the luciferase activities of NF- $\mathrm{KB}$ (about 2.3 fold of controls, $P<0.05$ ), indicating that Gli1 could enhance 


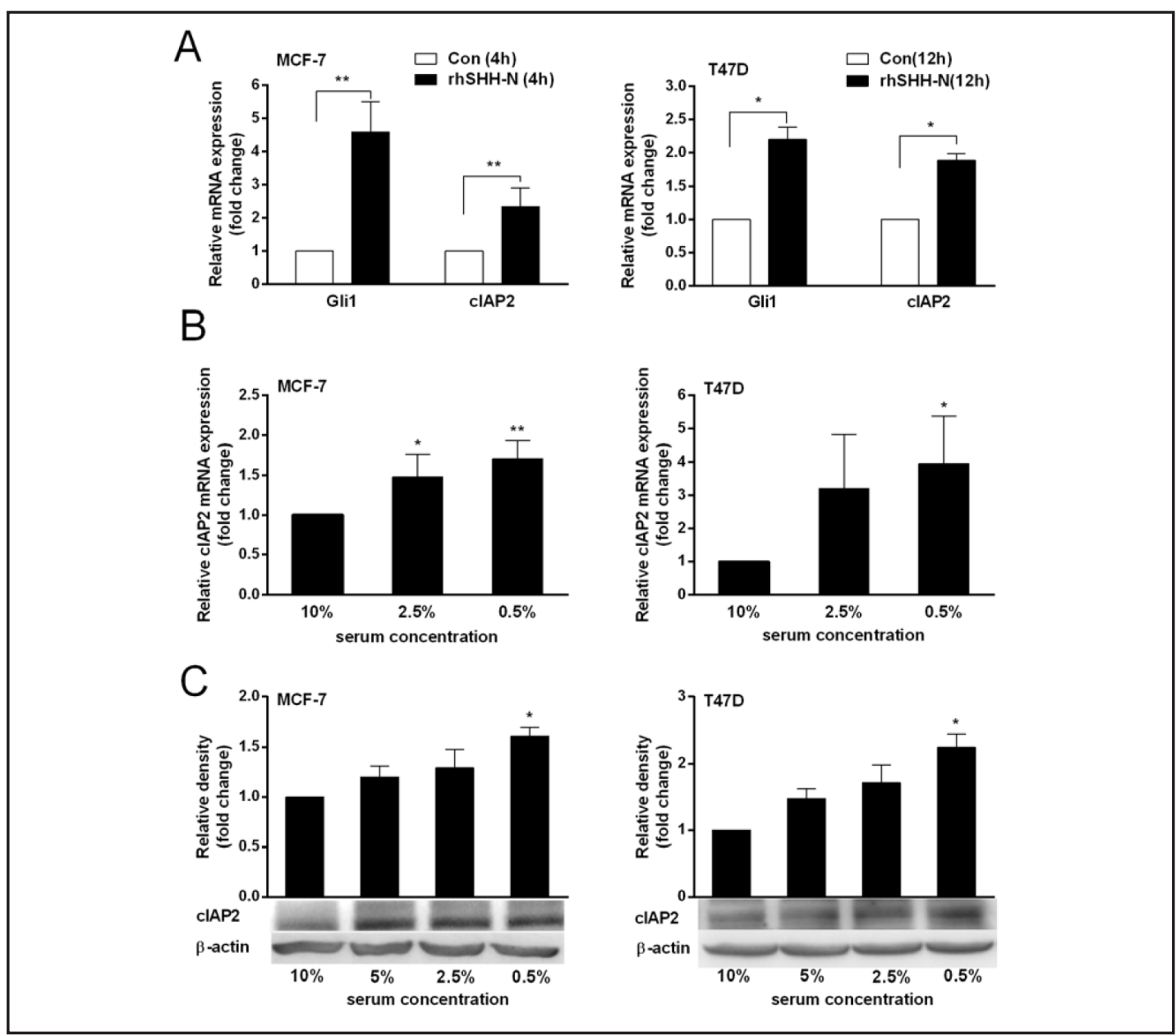

Fig. 5. Effect of activation of Hedgehog/Gli1 signaling pathway and serum starvation on cIAP2 expression in breast cancer cells. (A) MCF-7 and T47D cells were cultured for 24h in complete medium and then treated with or without $0.4 \mu \mathrm{g} / \mathrm{ml}$ rhSHH-N for indicated hours. Then Gli1 and cIAP2 mRNA expressions were determined by QRT-PCR. For serum starvation experiment, MCF-7 and T47D cells were incubated in medium containing indicated concentrations of serum for another $24 \mathrm{~h}$. Then cIAP2 mRNA (B) and protein (C) levels were tested. GAPDH was used as a normalization control for QRT-PCR and $\beta$-actin as a loading control for Western blotting. Data were representative of at least three independent experiments and expressed as mean \pm S.D. ${ }^{*} P<0.05,{ }^{* *} P<0.01$ versus the $10 \%$ group or the cells treated with the vehicle.

transcriptional activity of NF- $\kappa \mathrm{B}$ in MCF-7 cells. Inhibition of NF- $\kappa \mathrm{B}$ trans-activation using Bay11-7082 (Bay), a specific inhibitor of NF- $\kappa B$, significantly decreased the Gli1-increased mRNA levels of cIAP2 in MCF-7 and T47D transfectants as compared with that treated by DMSO (from about 11 fold to 6 fold for Gli1-MCF-7, $P<0.01$, and from about 5 fold to 2.8 fold for Gli1-T47D, $P<0.05$, respectively)(Fig. 6B). Moreover, Bay not only attenuated basal cell viabilities, but also reduced Gli1-enhanced cell viabilities under serum-starved condition (Fig. 6C). These results demonstrate that pro-survival effect of Gli1 is partially mediated by $\mathrm{NF}-\kappa \mathrm{B}$ activation and up-regulation of cIAP2 as a target gene of NF- $\kappa \mathrm{B}$.

\section{Discussion}

Serum supplemented to cell culture media supports cell growth by providing a broad spectrum of nutrients, macromolecules, attachment factors, hormones and growth factors. Serum starvation could reduce cell viability and induce cellular apoptosis [28, 29]. Tumor KARGER 

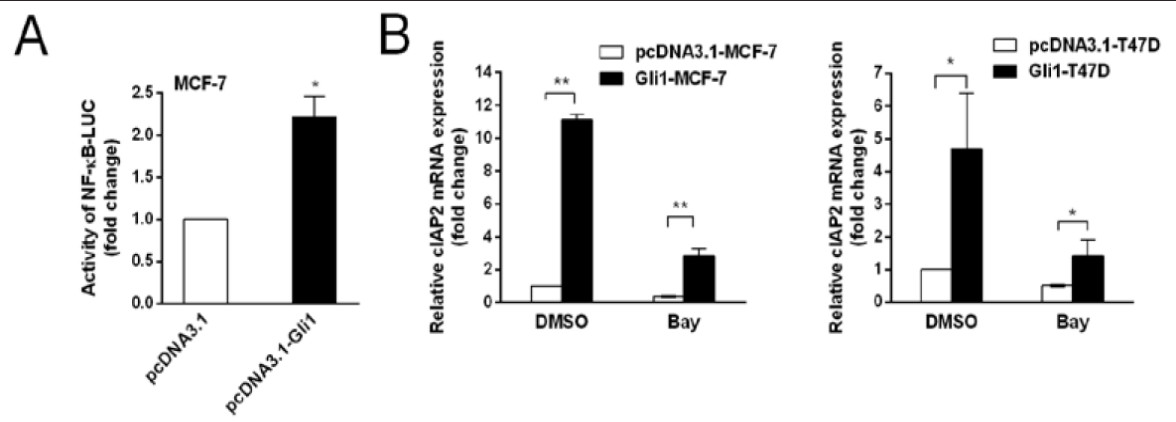

C
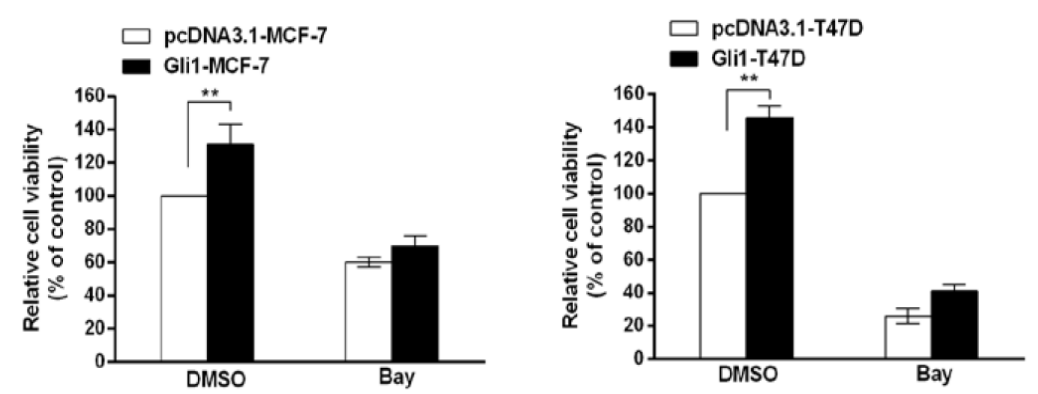

Fig. 6. Activation of NF- $\mathrm{KB} / \mathrm{cIAP} 2$ signaling is a potential pro-survival mechanism of Gli1 in breast cancer cells. (A) MCF-7 cells were co-transfected with 200ng of pGL3-NF-kB-luc, 1.0ng of pRL-SV40-luc, 500ng of pcDNA3.1-Gli1 or pcDNA3.1 vector in 24-well plate for 24h. The luciferase activities were measured and expressed as fold over the empty vector control. (B) cIAP2 mRNA level was assayed by QRT-PCR in MCF-7 and T47D cells with or without $5 \mu \mathrm{M}$ Bay (NF- $\kappa \mathrm{B}$ inhibitor) treatment for $12 \mathrm{~h}$. (C) MCF-7 or T47D cells were incubated in medium with $0.5 \%$ CD-FBS prior to treatment with $5 \mu \mathrm{M}$ Bay for $24 \mathrm{~h}$, and total incubation time was 4 days. The cell viability was determined at $450 \mathrm{~nm}$ on a microplate reader using WST-8 assay. Data were representative of three independent experiments. Each bar represents mean \pm S.D. ${ }^{*} P<0.05,{ }^{* *} P<0.01$ versus the empty vector control.

microenvironment is a characteristic of ischemia and starvation of nutrient, while the promotion of cell survival is a critical event in the development of cancer. In this study, we found that serum starvation significantly up-regulated the expression of Gli1 and overexpression of Gli1 promoted the survival of ER-positive breast cancer cells under a serumstarved condition. Furthermore, we found that serum starvation could activate AKT in MCF7 cells and T47D cells. Inhibiting PI3K/AKT pathway with Wortmanin significantly reduced the serum starvation-induced the expression of Gli1. These results indicated that activated PI3K/AKT pathway contributed to induction of Gli1 expression and pro-survival effect of Gli1 in a less nourished condition. Besides PI3K/AKT pathway, TGF $\beta$ and Ras/ERK pathway also modulate Gli1 expression and activity [6, 7]. Although these two pathways play an important role in control of cell survival in cancer cells, whether they are also involved in promoting survival of breast cancer cells by up-regulation of Gli1 expression under serum starvation is needed to be clarified.

Gli1 functions as a strong positive transcriptional activator in the downstream of the $\mathrm{Hh}$ pathway. So we first identified putative target genes that mediated the role of Gli1 in breast cancer cells by microarray analysis. We found that 338 genes were differentially expressed in Gli1-MCF-7 cells as compared with their control cells, which could be further divided into six functional groups: metabolism, apoptosis, cytoskeleton, proliferation, inflammation and innate immunity. Furthermore, among Gli1-regulated genes, up-regulation of cIAP2, SLFN5, SLPI, UBD genes and down-regulation of NDRG1 gene were confirmed by QRT-PCR in both Gli1-MCF-7 cells and Gli1-T47D cells. SLFN5 is a member of the Schlafen (SLFN) family and is involved in important functions, such as the control of cell proliferation, induction of 
immune responses, and the regulation of viral replication $[39,40]$. SLPI (secretory leucocyte protease inhibitor) is a secreted protease inhibitor which is found in various secreted fluids including seminal plasma, cervical mucus, and bronchial secretions [41]. UBD (Ubiquitin D/ Ubiquitin-like protein FAT 10) can be covalently attached to target protein and subsequently leads to their degradation by the 26S proteasome in a NUB1L-dependent manner [42]. NDRG1 is originally identified as a stress-responsive protein and belongs to a member of the $\mathrm{N}$-myc down-regulated family [43]. These proteins have been reported not only to regulate cell proliferation and metastasis, such as SLFN5 $[39,40]$, but also to play important roles in induction of immune and inflammatory responses [41]. So it is interesting to investigate whether Gli1 also plays an important role in control of immune and inflammatory responses mediated by these genes.

Among genes identified by the microarray, we noticed that three anti-apoptosis genes including CIAP2, TNFAIP3 and NUPR1 were up-regulated in Gli1-MCF-7 cells. Another group also reported the up-regulation of cIAP2 upon Gli1 over-expression in pancreatic cancer by microarray [44]. Since CIAP2 has well-established functions as an anti-apoptotic and prosurvival protein [32-34], we further investigated whether cIAP2 mediated the pro-survival effect of Gli1 as a potential target of Hh/Gli1 signaling. We found that expression of cIAP2 was not only up-regulated by over-expression of Gli1 and rhSHH-N, a ligand of Hh/Gli1 pathway, but also significantly increased by serum starvation. The regulation pattern and extent of cIAP2 were similar to the up-regulation of Gli1 by serum starvation, strongly suggesting that cIAP2 might be involved in the pro-survival effect of Gli1 in ER-positive breast cancer cells. Moreover, we investigated whether cIAP2 was a direct target gene of Gli1. Although a putative Gli1 binding site (5'-GATCCACCCA-3') within -1681bp to -1741bp promoter region of CIAP2 gene has been identified by transcription element search software analysis, ChIP assay did not reveal the direct binding of Gli1 to cIAP2 promoter at the region of -1568 to $-1792 \mathrm{bp}$, suggesting that cIAP2 is not a direct target gene of Gli1.

Transcription factor NF- $\mathrm{KB}$ is a strong pro-survival mediator in breast cancer cells. Constitutive activation of NF- $\mathrm{KB}$ in breast tumors is associated with highly aggressive ERpositive tumors [45, 46], development of the resistance to endocrine therapy $[47,48]$ and progression to estrogen-independent growth [49-51]. Ramirez E et al reported that activation of NF- $\kappa \mathrm{B}$ is associated with increased expression of Gli1 and Hh ligands since pharmacologic inhibition of NF- $\kappa \mathrm{B}$ pathway resulted in a decreased expression of Gli1 and Hh ligands in diffuse large B-cell lymphoma (DLBCL) [27]. On the contrary, we found that over-expression of Gli1 significantly enhanced transcriptional activity of NF- $\kappa B$ in MCF-7 cells. Several antiapoptotic and pro-survival genes such as cIAP2, Bcl-2, Bcl-xL and Survivin are regulated by

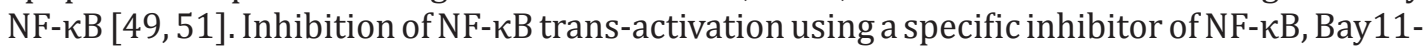
7082 (Bay) not only significantly reduced the pro-survival effect of Gli1, but also markedly decreased the up-regulation of cIAP2 mRNA expression in both Gli1-MCF-7 cells and Gli1T47D cells under a serum-starved condition. These results revealed that enhancing NF- $\kappa B$ signaling also contributed to the pro-survival effect of Gli1 by up-regulating its downstream anti-apoptotic and pro-survival genes, such as cIAP2 in breast cancer cells.

In summary, our data revealed that the up-regulation of Gli1 and its target cIAP2 by serum starvation promoted the survival of breast cancer cells. Gli1 also promoted cell survival by enhancing NF- $\mathrm{KB} / \mathrm{cIAP} 2$ signaling in breast cancer cells. These findings provide new insights into the pro-survival mechanisms of Gli1 and evidence of cross-talk between Gli1 signaling and NF- $\mathrm{BB}$ signaling in breast cancer. However, the mechanisms by which Gli1 enhances trans-activation of NF- $\mathrm{kB}$ are still unclear and further study is needed.

\section{Acknowledgements}

The authors thank Dr. Hiroshi Sasaki and Dr. H.M. Xu for providing plasmids. This work was supported by a scientific research grant from the National Natural Science Foundation of China (grant no. 30971157). 


\section{Cellular Physiology Cell Physiol Biochem 2015;36:1862-1876 \begin{tabular}{l|l} 
and Biochemistry Publisned onIIne: July 12, 2015 & $\begin{array}{l}\text { C) 2015 S. Karger AG, Basel } \\
\text { www.karger.com/cpb }\end{array}$ \\
\hline
\end{tabular} Xu et al.: Gli1 Promotes Survival of Breast Cancer Cells}

\section{Disclosure Statement}

The authors declare that they have no conflict of interest.

\section{References}

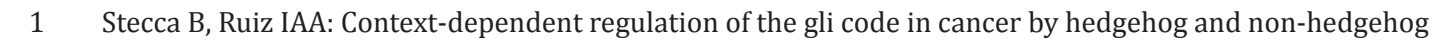
signals. J Mol Cell Biol 2010;2:84-95.

$>2$ Kasper M, Regl G, Frischauf AM, Aberger F: Gli transcription factors: Mediators of oncogenic hedgehog signalling. Eur J Cancer 2006;42:437-445.

-3 Kogerman P, Grimm T, Kogerman L, Krause D, Unden AB, Sandstedt B, Toftgard R, Zaphiropoulos PG: Mammalian suppressor-of-fused modulates nuclear-cytoplasmic shuttling of gli-1. Nat Cell Biol 1999;1:312-319.

4 Kinzler KW, Vogelstein B: The gli gene encodes a nuclear protein which binds specific sequences in the human genome. Mol Cell Biol 1990;10:634-642.

5 Lee J, Platt KA, Censullo P, Ruiz i Altaba A: Gli1 is a target of sonic hedgehog that induces ventral neural tube development. Development 1997;124:2537-2552.

6 Dennler S, Andre J, Alexaki I, Li A, Magnaldo T, ten Dijke P, Wang XJ, Verrecchia F, Mauviel A: Induction of sonic hedgehog mediators by transforming growth factor-beta: Smad3-dependent activation of gli2 and gli1 expression in vitro and in vivo. Cancer Res 2007;67:6981-6986.

7 Ramaswamy B, Lu Y, Teng KY, Nuovo G, Li X, Shapiro CL, Majumder S: Hedgehog signaling is a novel therapeutic target in tamoxifen-resistant breast cancer aberrantly activated by pi3k/akt pathway. Cancer Res 2012;72:5048-5059.

-8 Schnidar H, Eberl M, Klingler S, Mangelberger D, Kasper M, Hauser-Kronberger C, Regl G, Kroismayr R, Moriggl R, Sibilia M, Aberger F: Epidermal growth factor receptor signaling synergizes with hedgehog/gli in oncogenic transformation via activation of the mek/erk/jun pathway. Cancer Res 2009;69:1284-1292.

-9 Teh MT, Wong ST, Neill GW, Ghali LR, Philpott MP, Quinn AG: Foxm1 is a downstream target of gli1 in basal cell carcinomas. Cancer Res 2002;62:4773-4780.

-10 Yoon JW, Kita Y, Frank DJ, Majewski RR, Konicek BA, Nobrega MA, Jacob H, Walterhouse D, Iannaccone P: Gene expression profiling leads to identification of gli1-binding elements in target genes and a role for multiple downstream pathways in gli1-induced cell transformation. J Biol Chem 2002;277:5548-5555.

11 Feldmann G, Dhara S, Fendrich V, Bedja D, Beaty R, Mullendore M, Karikari C, Alvarez H, IacobuzioDonahue C, Jimeno A, Gabrielson KL, Matsui W, Maitra A: Blockade of hedgehog signaling inhibits pancreatic cancer invasion and metastases: A new paradigm for combination therapy in solid cancers. Cancer Res 2007;67:2187-2196.

-12 Nagai S, Nakamura M, Yanai K, Wada J, Akiyoshi T, Nakashima H, Ohuchida K, Sato N, Tanaka M, Katano M: Gli1 contributes to the invasiveness of pancreatic cancer through matrix metalloproteinase- 9 activation. Cancer Sci 2008;99:1377-1384.

13 Kubo M, Nakamura M, Tasaki A, Yamanaka N, Nakashima H, Nomura M, Kuroki S, Katano M: Hedgehog signaling pathway is a new therapeutic target for patients with breast cancer. Cancer Res 2004;64:60716074.

14 Mukherjee S, Frolova N, Sadlonova A, Novak Z, Steg A, Page GP, Welch DR, Lobo-Ruppert SM, Ruppert JM, Johnson MR, Frost AR: Hedgehog signaling and response to cyclopamine differ in epithelial and stromal cells in benign breast and breast cancer. Cancer Biol Ther 2006;5:674-683.

15 Zhang X, Harrington N, Moraes RC, Wu MF, Hilsenbeck SG, Lewis MT: Cyclopamine inhibition of human breast cancer cell growth independent of smoothened (smo). Breast Cancer Res Treat 2009;115:505-521.

16 Teglund S, Toftgard R: Hedgehog beyond medulloblastoma and basal cell carcinoma. Biochim Biophys Acta 2010;1805:181-208.

17 Thayer SP, di Magliano MP, Heiser PW, Nielsen CM, Roberts DJ, Lauwers GY, Qi YP, Gysin S, Fernandezdel Castillo C, Yajnik V, Antoniu B, McMahon M, Warshaw AL, Hebrok M: Hedgehog is an early and late mediator of pancreatic cancer tumorigenesis. Nature 2003;425:851-856.

-18 Kasper M, Jaks V, Fiaschi M, Toftgard R: Hedgehog signalling in breast cancer. Carcinogenesis 2009;30:903911. 


\section{Cellular Physiology Cell Physiol Biochem 2015;36:1862-1876

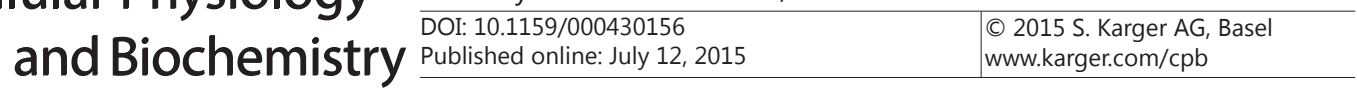

Xu et al.: Gli1 Promotes Survival of Breast Cancer Cells

19 ten Haaf A, Bektas N, von Serenyi S, Losen I, Arweiler EC, Hartmann A, Knuchel R, Dahl E: Expression of the glioma-associated oncogene homolog (gli) 1 in human breast cancer is associated with unfavourable overall survival. BMC Cancer 2009;9:298.

20 O'Toole SA, Machalek DA, Shearer RF, Millar EK, Nair R, Schofield P, McLeod D, Cooper CL, McNeil CM, McFarland A, Nguyen A, Ormandy CJ, Qiu MR, Rabinovich B, Martelotto LG, Vu D, Hannigan GE, Musgrove EA, Christ D, Sutherland RL, Watkins DN, Swarbrick A: Hedgehog overexpression is associated with stromal interactions and predicts for poor outcome in breast cancer. Cancer Res 2011;71:4002-4014.

21 Fiaschi M, Rozell B, Bergstrom A, Toftgard R: Development of mammary tumors by conditional expression of gli1. Cancer Res 2009;69:4810-4817.

22 Zhao J, Chen G, Cao D, Li Y, Diao F, Cai H, Jin Y, Lu J: Expression of gli1 correlates with the transition of breast cancer cells to estrogen-independent growth. Breast Cancer Res Treat 2010;119:39-51.

-23 Xu H, An H, Yu Y, Zhang M, Qi R, Cao X: Ras participates in cpg oligodeoxynucleotide signaling through association with toll-like receptor 9 and promotion of interleukin-1 receptor-associated kinase/ tumor necrosis factor receptor-associated factor 6 complex formation in macrophages. J Biol Chem 2003;278:36334-36340.

24 Clark AS, West K, Streicher S, Dennis PA: Constitutive and inducible akt activity promotes resistance to chemotherapy, trastuzumab, or tamoxifen in breast cancer cells. Mol Cancer Ther 2002;1:707-717.

$25 \mathrm{Wu}$ J, Chen C, Zhao KN: Phosphatidylinositol 3-kinase signaling as a therapeutic target for cervical cancer. Curr Cancer Drug Targets 2013;13:143-156.

-26 Stecca B, Mas C, Clement V, Zbinden M, Correa R, Piguet V, Beermann F, Ruiz IAA: Melanomas require hedgehog-gli signaling regulated by interactions between gli1 and the ras-mek/akt pathways. Proc Natl Acad Sci U S A 2007;104:5895-5900.

27 Ramirez E, Singh RR, Kunkalla K, Liu Y, Qu C, Cain C, Multani AS, Lennon PA, Jackacky J, Ho M, Dawud S, Gu J, Yang S, Hu PC, Vega F: Defining causative factors contributing in the activation of hedgehog signaling in diffuse large b-cell lymphoma. Leuk Res 2012;36:1267-1273.

28 Kou X, Jing Y, Deng W, Sun K, Han Z, Ye F, Yu G, Fan Q Gao L, Zhao Q Zhao X, Li R, Wei L, Wu M: Tumor necrosis factor-alpha attenuates starvation-induced apoptosis through upregulation of ferritin heavy chain in hepatocellular carcinoma cells. BMC Cancer 2013;13:1471-2407.

29 Enervald E, Du L, Visnes T, Bjorkman A, Lindgren E, Wincent J, Borck G, Colleaux L, Cormier-Daire V, van Gent DC, Pie J, Puisac B, de Miranda NF, Kracker S, Hammarstrom L, de Villartay JP, Durandy A, Schoumans J, Strom L, Pan-Hammarstrom Q: A regulatory role for the cohesin loader nipbl in nonhomologous end joining during immunoglobulin class switch recombination. J Exp Med 2013;210:2503-2513.

-30 Xu W, Xue L, Sun Y, Henry A, Battle JM, Micault M, Morris SW: Bcl10 is an essential regulator for a20 gene expression. J Physiol Biochem 2013;69:821-834.

31 Hamidi T, Algul H, Cano CE, Sandi MJ, Molejon MI, Riemann M, Calvo EL, Lomberk G, Dagorn JC, Weih F, Urrutia R, Schmid RM, Iovanna JL: Nuclear protein 1 promotes pancreatic cancer development and protects cells from stress by inhibiting apoptosis. J Clin Invest 2012;122:2092-2103.

-32 Bertrand MJ, Milutinovic S, Dickson KM, Ho WC, Boudreault A, Durkin J, Gillard JW, Jaquith JB, Morris SJ, Barker PA: Ciap1 and ciap2 facilitate cancer cell survival by functioning as e3 ligases that promote rip1 ubiquitination. Mol Cell 2008;30:689-700.

-33 Miura K, Karasawa H, Sasaki I: Ciap2 as a therapeutic target in colorectal cancer and other malignancies. Expert Opin Ther Targets 2009;13:1333-1345.

34 de Almagro MC, Vucic D: The inhibitor of apoptosis (iap) proteins are critical regulators of signaling pathways and targets for anti-cancer therapy. Exp Oncol 2012;34:200-211.

35 Ho L, Stojanovski A, Whetstone H, Wei QX, Mau E, Wunder JS, Alman B: Gli2 and p53 cooperate to regulate igfbp-3- mediated chondrocyte apoptosis in the progression from benign to malignant cartilage tumors. Cancer Cell 2009;16:126-136.

-36 Liu ZG, Hsu H, Goeddel DV, Karin M: Dissection of tnf receptor 1 effector functions: Jnk activation is not linked to apoptosis while nf-kappab activation prevents cell death. Cell 1996;87:565-576.

-37 Momeny M, Zakidizaji M, Ghasemi R, Dehpour AR, Rahimi-Balaei M, Abdolazimi Y, Ghavamzadeh A, Alimoghaddam K, Ghaffari SH: Arsenic trioxide induces apoptosis in nb-4, an acute promyelocytic leukemia cell line, through up-regulation of p73 via suppression of nuclear factor kappa b-mediated inhibition of p73 transcription and prevention of nf-kappab-mediated induction of xiap, ciap2, bcl-xl and survivin. Med Oncol 2010;27:833-842. 


\section{Cellular Physiology Cell Physiol Biochem 2015;36:1862-1876

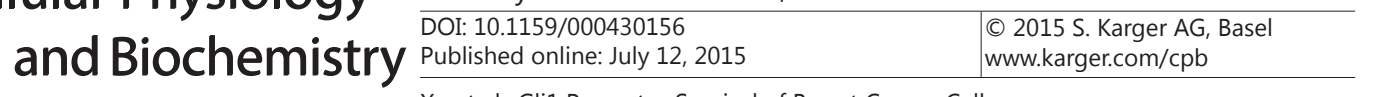 \\ Xu et al.: Gli1 Promotes Survival of Breast Cancer Cells}

-38 Zhao X, Laver T, Hong SW, Twitty GB, Jr., Devos A, Devos M, Benveniste EN, Nozell SE: An nf-kappab p65ciap2 link is necessary for mediating resistance to tnf-alpha induced cell death in gliomas. J Neurooncol 2011;102:367-381.

-39 Mavrommatis E, Fish EN, Platanias LC: The schlafen family of proteins and their regulation by interferons. J Interferon Cytokine Res 2013;33:206-210.

-40 Katsoulidis E, Mavrommatis E, Woodard J, Shields MA, Sassano A, Carayol N, Sawicki KT, Munshi HG, Platanias LC: Role of interferon \{alpha\} (IFN\{alpha\})-inducible schlafen-5 in regulation of anchorageindependent growth and invasion of malignant melanoma cells. J Biol Chem 2010;285:40333-40341.

41 Williams SE, Brown TI, Roghanian A, Sallenave JM: Slpi and elafin: One glove, many fingers. Clin Sci (Lond) 2006;110:21-35.

42 Hipp MS, Kalveram B, Raasi S, Groettrup M, Schmidtke G: Fat10, a ubiquitin-independent signal for proteasomal degradation. Mol Cell Biol 2005;25:3483-3491.

43 Ellen TP, Ke Q, Zhang P, Costa M: Ndrg1, a growth and cancer related gene: Regulation of gene expression and function in normal and disease states. Carcinogenesis 2008;29:2-8.

44 Feldmann G, Habbe N, Dhara S, Bisht S, Alvarez H, Fendrich V, Beaty R, Mullendore M, Karikari C, Bardeesy N, Ouellette MM, Yu W, Maitra A: Hedgehog inhibition prolongs survival in a genetically engineered mouse model of pancreatic cancer. Gut 2008;57:1420-1430.

45 Zhou Y, Eppenberger-Castori S, Eppenberger U, Benz CC: The nfkappab pathway and endocrine-resistant breast cancer. Endocr Relat Cancer 2005;12:S37-46.

-46 Zhou Y, Eppenberger-Castori S, Marx C, Yau C, Scott GK, Eppenberger U, Benz CC: Activation of nuclear factor-kappab (nfkappab) identifies a high-risk subset of hormone-dependent breast cancers. Int J Biochem Cell Biol 2005;37:1130-1144.

47 deGraffenried LA, Chandrasekar B, Friedrichs WE, Donzis E, Silva J, Hidalgo M, Freeman JW, Weiss GR: Nfkappa b inhibition markedly enhances sensitivity of resistant breast cancer tumor cells to tamoxifen. Ann Oncol 2004;15:885-890.

48 Riggins RB, Zwart A, Nehra R, Clarke R: The nuclear factor kappa b inhibitor parthenolide restores ici 182,780 (faslodex; fulvestrant)-induced apoptosis in antiestrogen-resistant breast cancer cells. Mol Cancer Ther 2005;4:33-41.

49 Nakshatri H, Bhat-Nakshatri P, Martin DA, Goulet RJ Jr, Sledge GW Jr: Constitutive activation of nf-kappab during progression of breast cancer to hormone-independent growth. Mol Cell Biol 1997;17:3629-3639.

50 Biswas DK, Dai SC, Cruz A, Weiser B, Graner E, Pardee AB: The nuclear factor kappa b (nf-kappa b): A potential therapeutic target for estrogen receptor negative breast cancers. Proc Natl Acad Sci U S A 2001;98:10386-10391.

51 Biswas DK, Shi Q, Baily S, Strickland I, Ghosh S, Pardee AB, Iglehart JD: Nf-kappa b activation in human breast cancer specimens and its role in cell proliferation and apoptosis. Proc Natl Acad Sci U S A 2004;101:10137-10142. 